\title{
Sialate O-Acetylesterase
}

National Cancer Institute

\section{Source}

National Cancer Institute. Sialate O-Acetylesterase. NCI Thesaurus. Code C91284.

Sialate O-acetylesterase ( $523 \mathrm{aa}, \sim 58 \mathrm{kDa}$ ) is encoded by the human SIAE gene. This protein plays a role in the removal of O-acetyl ester groups from sialic acid. 